\title{
High Altitude Diving Depths
}

\author{
Poul-Erik Paulev ${ }^{1,2}$ and Gustavo Zubieta-Calleja, $\mathrm{Jr}^{2,1}$ \\ ${ }^{1}$ Department of Medical Physiology, \\ The Panum Institute, University of Copenhagen, Denmark, \\ and $^{2}$ The High Altitude Pathology Institute, La Paz, Bolivia.
}

Corresponding author:

Poul-Erik Paulev, Department of Medical Physiology,

The Panum Institute, University of Copenhagen,

3 Blegdamsvej, DK-2200 Copenhagen NV.

Tel: +4545813271

E-mail:pepaulev@yahoo.dk

This is a preprint copy. Original copy can be found at:

\section{High Altitude Diving Depths}

Poul-Erik Paulev; Gustavo Zubieta-Calleja

DOI: $10.1080 / 15438620701526795$

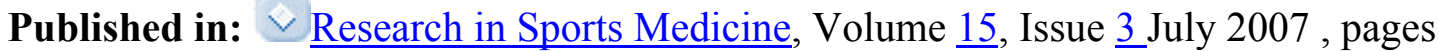
$213-223$ 


\section{Abstract}

In order to make any sea level dive table usable during high altitude diving, a new conversion factor is created. We introduce the Standardized Equivalent Sea Depth (SESD), which allows conversion of the Actual Lake Diving Depth (ALDD) to an equivalent sea dive depth.

SESD is defined as the sea depth in meters or feet for a standardized sea dive, equivalent to a mountain lake dive at any altitude, such that:

$$
\begin{aligned}
& \mathrm{SESD}=\mathrm{ALDD} *[\text { Nitrogen ratio }] *[\text { Water density ratio }] \\
& \mathrm{SESD}=\mathrm{ALDD} *\left[(760-47) /\left(\mathrm{P}_{\mathrm{B}}-47\right)\right] *[1000 / 1033] \\
& \mathrm{SESD}=\mathrm{ALDD} *[\mathrm{SESD} \text { factor }]
\end{aligned}
$$

Mountain lakes contain fresh water with a relative density that can be standardized to $1000 \mathrm{~kg} \mathrm{~m}^{-3}$, and sea water can likewise be standardized to a relative density of $1033 \mathrm{~kg}$ $\mathrm{m}^{-3}$, at the general gravity of $9.80665 \mathrm{~m} \mathrm{~s}^{-2}$. The Water density ratio $(1000 / 1033)$ refers to the fresh lake water and the standardized sea water densities.

Following calculation of the SESD factor, we recommend the use of our simplified diving table or any acceptable sea level dive table with 2 fundamental guidelines:

1. The classical decompression stages $(30,20$ and 10 feet or 9,6 and $3 \mathrm{~m})$ are corrected to the altitude lake level, dividing the stage depth by the SESD factor.

2. Likewise, the Lake ascent rate during diving is equal to the Sea ascent rate divided by the SESD factor.

\section{Key words}


Decompression sickness; Dive Tables; High altitude diving; Water density.

\section{Introduction}

A relatively higher risk of developing decompression sickness (DCS) is probably present when diving in mountain lakes in contrast to the sea.

Bell and Borgwardt (1976) converted the diving depth at altitude to an equivalent depth in the sea. Previous conversions were entirely based on the ratio of the atmospheric pressure at altitude to that at sea level. The difference in density between fresh and salt water was not included in the correction. Bell and Borgwardt (1976) adjusted the ascent rate in the Cross tables and dived in lake Tahoe without DCS.

Bo"ni, Schibli, Nussberger et al (1976) developed altitude decompression tables and performed wet dives up to $2000 \mathrm{~m}$ above sea level in the Swiss mountains without DCS. Hennesy (1977) proposed formulas for converting standard air decompression tables for no-stop diving at altitude. Predictions were in agreement with the Swiss diving tables, that are available in Buhlman's book (1984) and at the internet (2005).

Sahni, Dhall and Chatterjee (1991) converted depths at altitude to depths at sea level and used the Royal Navy Air Tables. They concluded that equivalent air depths applied to Royal Navy tables is a safe method for diving at altitude.

None of these strategies are easy to use for the recreational diver. The purpose of the present report was to develop a scientifically based and practical model for dive tables used at high altitude.

\section{Methods}


An essential determinant for $\mathrm{N}_{2}$ exchange between the body and the surrounding breathing medium is the $\mathrm{N}_{2}$ tension in the water vapor-saturated, tracheal air $\left(\mathrm{P}_{\mathrm{IN} 2}\right)$. This value is a feeding pressure to the body during loading and a receiving pressure during unloading of the body from $\mathrm{N}_{2}$. In both cases the body can be considered a black box as far as the model is concerned. At any altitude above sea level, the barometric pressure $\left(\mathrm{P}_{\mathrm{B}}\right)$ is below 1 atmospheres absolute pressure $\left(\mathrm{P}_{\mathrm{B}}<760\right.$ Torr). The effect of the tracheal water vapor pressure increases with increasing altitude, therefore this constant (47 Torr or 6.3 $\mathrm{kPa}$ ) value must be included in the model. The ratio between the inspired tracheal $\mathrm{N}_{2}$ tension at any $\mathrm{P}_{\mathrm{B}}$ and that at sea level (1 atm abs) must be:

$$
\mathrm{F}_{\mathrm{IN} 2}\left(\mathrm{P}_{\mathrm{B}}-47\right) / \mathrm{F}_{\mathrm{IN} 2}(760-47)
$$

using the unit Torr $(=\mathrm{mmHg})$. The dry, inspired Nitrogen fraction $\left(\mathrm{F}_{\mathrm{IN} 2}\right)$ is constant and eliminated, resulting in:

$$
\left(\mathrm{P}_{\mathrm{B}}-47\right) /(760-47)
$$

This is actually equal to the Nitrogen tension ratio for loading as well as for unloading the body from $\mathrm{N}_{2}$ at any typical altitude- $\mathrm{P}_{\mathrm{B}}$ relative to sea level (760 Torr). The partial pressure of saturated water vapour at body temperature - constantly equal to $6.3 \mathrm{kPa}$ or 47 Torr as long as the body temperature remains normal - obviously plays a larger role at increasing altitude. For example, at $470 \mathrm{mmHg}$ of $\mathrm{P}_{\mathrm{B}}$, the water vapour pressure (47 Torr at $37^{\circ} \mathrm{C}$ ) amounts to $10 \%$.

Most mountain lakes contain fresh water with a relative density that can be standardized to $1000 \mathrm{~kg} \mathrm{~m}^{-3}$, and seawater can likewise be standardized to a relative density of $1033 \mathrm{~kg}$ $\mathrm{m}^{-3}$, at the general gravity of $9.80665 \mathrm{~m} \mathrm{~s}^{-2}$. With fresh water and standardized seawater 
the Water density ratio is $(1000 / 1033)$. The difference in relative density of lake water and seawater also affects the size of the inspired nitrogen pressure.

\section{Adaptation of the diver to altitude}

A diver spending more than one day following arrival to altitude, will be more or less adapted to the environment including the low partial pressure of nitrogen in the inspired air of the trachea.

\section{Standardized Equivalent Sea Depth (SESD)}

In order to make sea level diving tables usable during high altitude diving, a new terminology for comparison purposes is created. It must be an acceptable strategy to develop an accurate correction factor, so it is possible to convert the actual lake diving depth (ALDD) to an equivalent sea dive depth. The risk of contacting DCS increases during ascent following exposure to a higher partial pressure of nitrogen due to the dive. This is because such a rise leads to a proportional rise in the nitrogen gradient between the body and the environment, hereby increasing the body load of nitrogen compared to that at the surface of the lake. This is a relativity model describing loading and de-loading of nitrogen.

SESD is defined as the sea depth in meters ( $\mathrm{m}$ or msw) for a standardized sea dive, equivalent to a mountain lake dive at any altitude. The sea dive is standardized in air saturated salt seawater with a relative density of $1033 \mathrm{~kg} \mathrm{~m}^{-3}$, at the general gravity of $9.80665 \mathrm{~m} \mathrm{~s}^{-2}$. Hereby, a standardized $10 \mathrm{~m}$ seawater column corresponds to 1 
atmosphere. With fresh water and standardized seawater the Water density ratio is $(1000 / 1033)$ - as developed above.

\section{Calculation of the SESD factor}

The actual lake diving depth (ALDD) is converted to SESD by correction for the relative change in typical barometric pressure $\left(\mathrm{P}_{\mathrm{B}}\right.$ Torr) at altitude compared to 760 Torr, and thus the relative change in nitrogen pressure in the inspired air $(760-47) /\left(P_{B}-47\right)$. This is therefore equal to the true inspired nitrogen ratio.

$$
\begin{aligned}
& \mathrm{SESD}=\mathrm{ALDD}^{*}[\text { Nitrogen ratio }]^{*}[\text { Water density ratio }] \\
& \mathrm{SESD}=\mathrm{ALDD}^{*}\left[(760-47) /\left(\mathrm{P}_{\mathrm{B}}-47\right)\right]^{*}[1000 / 1033] \\
& \mathrm{SESD}=\mathrm{ALDD} *[\mathrm{SESD} \text { factor }]
\end{aligned}
$$

\section{Calculation of the rate of descent and ascent}

The rate of ascent/descent from a standard sea dive table is called Sea rate. - Feet (yards) are transferred to meters. - Now the Lake ascent rate is equal to the Sea ascent rate divided by the SESD factor.

\section{Decompression Stages}

Assuming the classical sea level decompression stages to be valid, we need to compensate for the relative pressure changes at altitude. Therefore, the classical sea level decompression stages must be recalculated dividing by the SESD factor. 


\section{Results}

\section{Modified US Navy dive tables}

Now a suitable dive table for sea diving can be followed. We have chosen to modify the US Navy dive table shown below (US Navy Diving Manual 1963). This table is running to a maximum of $60 \mathrm{~m}$ at sea level (Table 1), because it is for Navy and professional divers. In fact $100 \mathrm{fsw}$ (equivalent to around $30 \mathrm{~m}$ ) is considered the max depth for recreational and sport diving (Kizer 2001).

Table 1. The depth is converted from "unified feet" to meters and rounded-off. The diving time is the period from the diver leaves the water surface until the time when he starts to ascend from the bottom. The recommended Total Ascent Period (rounded-off) from depth is based on the maximal allowable ascent rate of $30 \mathrm{feet} / \mathrm{min}(9 \mathrm{~m} / \mathrm{min})$ including necessary stage stops. It is recommended to stop always for an extra 1 minute at the last decompression stage (with an extra SCUBA apparatus) to obtain proper offgassing. This table only allows one dive per day. 
Table 1. Modified US Navy Dive Table for standard dives at sea level

Zubieta \& Paulev.

\begin{tabular}{|c|c|c|c|c|c|c|}
\hline \multicolumn{2}{|c|}{ Diving Depth } & \multirow{2}{*}{$\begin{array}{c}\text { Diving } \\
\text { time }\end{array}$} & \multicolumn{3}{|c|}{ Decompression Stages } & \multirow{2}{*}{$\frac{\text { Total Ascent Period }}{\text { Minutes }}$} \\
\hline Feet & Meters & & $30 \mathrm{ft}=9 \mathrm{~m}$ & $20 \mathrm{ft}=6 \mathrm{~m}$ & $10 \mathrm{ft}=3 \mathrm{~m}$ & \\
\hline 35 & 11 & $\begin{array}{l}310 \\
320 \\
\end{array}$ & & & $\begin{array}{l}1 \\
2 \\
\end{array}$ & $\begin{array}{l}2 \\
3 \\
\end{array}$ \\
\hline 40 & 12 & $\begin{array}{l}200 \\
210 \\
230 \\
\end{array}$ & & & $\begin{array}{l}1 \\
2 \\
7\end{array}$ & $\begin{array}{l}2 \\
3 \\
8\end{array}$ \\
\hline 50 & 15 & $\begin{array}{l}100 \\
110 \\
120\end{array}$ & & & $\begin{array}{l}1 \\
3 \\
5\end{array}$ & $\begin{array}{l}3 \\
5 \\
7\end{array}$ \\
\hline 60 & 18 & $\begin{array}{l}60 \\
70 \\
80 \\
\end{array}$ & & & $\begin{array}{l}1 \\
2 \\
7 \\
\end{array}$ & $\begin{array}{l}3 \\
4 \\
9\end{array}$ \\
\hline 70 & 21 & $\begin{array}{l}50 \\
60 \\
70 \\
\end{array}$ & & & \begin{tabular}{c|}
1 \\
8 \\
14 \\
\end{tabular} & $\begin{array}{c}3 \\
10 \\
16 \\
\end{array}$ \\
\hline 80 & 24 & $\begin{array}{l}40 \\
50 \\
60\end{array}$ & & & $\begin{array}{c}1 \\
10 \\
17\end{array}$ & $\begin{array}{c}4 \\
13 \\
20 \\
\end{array}$ \\
\hline 90 & 27 & $\begin{array}{l}30 \\
40 \\
50 \\
\end{array}$ & & & $\begin{array}{c}1 \\
7 \\
18 \\
\end{array}$ & \begin{tabular}{c|}
4 \\
10 \\
21 \\
\end{tabular} \\
\hline 100 & 30 & $\begin{array}{l}25 \\
30 \\
40\end{array}$ & & & $\begin{array}{c}1 \\
3 \\
15\end{array}$ & $\begin{array}{c}4 \\
6 \\
18 \\
\end{array}$ \\
\hline 110 & 34 & $\begin{array}{l}20 \\
25 \\
30 \\
\end{array}$ & & & $\begin{array}{l}1 \\
3 \\
7 \\
\end{array}$ & $\begin{array}{c}5 \\
7 \\
11 \\
\end{array}$ \\
\hline 120 & 37 & $\begin{array}{l}15 \\
20 \\
25\end{array}$ & & & $\begin{array}{l}1 \\
2 \\
6\end{array}$ & $\begin{array}{c}5 \\
6 \\
10 \\
\end{array}$ \\
\hline 130 & 40 & $\begin{array}{l}10 \\
15 \\
20\end{array}$ & & & $\begin{array}{l}1 \\
2 \\
4\end{array}$ & $\begin{array}{l}5 \\
6 \\
8\end{array}$ \\
\hline 140 & 43 & $\begin{array}{l}10 \\
15 \\
20 \\
\end{array}$ & & & $\begin{array}{l}1 \\
2 \\
6\end{array}$ & $\begin{array}{c}6 \\
7 \\
11 \\
\end{array}$ \\
\hline 150 & 46 & $\begin{array}{c}5 \\
10 \\
15 \\
20 \\
\end{array}$ & & 2 & $\begin{array}{l}1 \\
2 \\
3 \\
7 \\
\end{array}$ & $\begin{array}{c}6 \\
7 \\
8 \\
14 \\
\end{array}$ \\
\hline 160 & 49 & $\begin{array}{c}5 \\
10 \\
15 \\
20\end{array}$ & & $\begin{array}{l}1 \\
3\end{array}$ & $\begin{array}{c}1 \\
2 \\
4 \\
11\end{array}$ & $\begin{array}{c}6 \\
7 \\
10 \\
19\end{array}$ \\
\hline 170 & 52 & $\begin{array}{c}5 \\
10 \\
15 \\
20\end{array}$ & & $\begin{array}{l}2 \\
4\end{array}$ & $\begin{array}{c}1 \\
2 \\
5 \\
15 \\
\end{array}$ & $\begin{array}{c}7 \\
8 \\
13 \\
19 \\
\end{array}$ \\
\hline 180 & 55 & $\begin{array}{c}5 \\
10 \\
15 \\
20\end{array}$ & 1 & $\begin{array}{l}3 \\
5\end{array}$ & $\begin{array}{c}1 \\
3 \\
6 \\
17\end{array}$ & $\begin{array}{c}7 \\
9 \\
15 \\
29 \\
\end{array}$ \\
\hline 190 & 58 & $\begin{array}{c}5 \\
10 \\
15 \\
20\end{array}$ & 2 & $\begin{array}{l}1 \\
4 \\
6\end{array}$ & $\begin{array}{c}1 \\
3 \\
7 \\
20\end{array}$ & $\begin{array}{c}7 \\
10 \\
17 \\
34\end{array}$ \\
\hline
\end{tabular}


In order to reduce the risk of DCS further, we suggest to stop at the last decompression stage ( $3 \mathrm{~m}$ for sea diving) for $1 \mathrm{~min}$ after any dive, since bubbles have been recorded with ultrasound even from a saturation dive below $5 \mathrm{~m}$. The modified US Navy dive table shown below is running to a maximum of $60 \mathrm{~m}$ (190 ft or $57.9 \mathrm{~m}$ in Table 1). Recall as mentioned above, recreational diving is recommended down to $100 \mathrm{fsw}$ or $30 \mathrm{~m}$ of depth.

\section{Specific mountain lakes}

\section{LAKE NYASA}

Lake Nyasa - with a surface area of $6,400 \mathrm{~km}^{2}$ - is located at an altitude of $500 \mathrm{~m}(1641$ ft) corresponding to a typical barometric pressure of 715 Torr.

The SESD factor, in this case, is equal to $[(760-47) /(715-47)]^{*}[1000 / 1033]$ or 1.03 . Obviously, there is no need for any correction, and any sea level dive table can be used, just like the modified US Navy dive table presented in Table 1.

\section{LAKE TITICACA}

At the surface of the Titicaca Lake, the largest navigable high altitude lake in the world, located in Bolivia and Peru at $3810 \mathrm{~m}$, there is a typical $\mathrm{P}_{\mathrm{B}}$ of 480 Torr. Let us consider an actual lake dive to a depth of $38 \mathrm{~m}$ :

$$
\begin{aligned}
& \mathrm{SESD}=38^{*}[(760-47) /(480-47)]^{*}[1000 / 1033] \\
& \mathrm{SESD}=38^{*}[1.6466]^{*}[0.968] \\
& \mathrm{SESD}=\mathrm{ALDD} *[\mathrm{SESD} \text { factor }] \\
& \mathrm{SESD}=38 * 1.594=60.6 \mathrm{~m} \text { seawater. }
\end{aligned}
$$

At Titicaca the SESD factor is therefore equal to 1.594 . 
We have chosen to recalculate the classical decompression stages $(3,6$ and $9 \mathrm{~m}$ corresponding to 10, 20 and $30 \mathrm{ft}$ of depth) by division with the value of the SESD factor. At Lake Titicaca the 3 calculated stages are 2, 4 and $6 \mathrm{~m}$ of depth.

Notice that a $38 \mathrm{~m}$ Titicaca dive is as dangerous as a $60 \mathrm{~m}$ sea dive due to the larger relative pressure exposure. The limit depth for compressed air dives is 60 meters at sea level or any comparable altitude dive.

A new dive Table for Lake Titicaca (Table 2) is developed on the basis of Table 1. The maximally recommended dive depth is $36 \mathrm{~m}$ or $119 \mathrm{ft}$ and only for a short period.

Table 2. The Total Ascent Period recommended is based on the maximal allowable ascent rate of $19 \mathrm{feet} / \mathrm{min}(6 \mathrm{~m} / \mathrm{min})$ from depth and includes necessary decompression stage stops. It is recommended to always stop during 1 minute at the last stage to obtain proper off-gassing. This table only allows one dive per day. 
Table 2. Modified US Navy Dive Table for Lake Titicaca (3810 m; standard dives with compressed air). Zubieta \& Paulev.

\begin{tabular}{|c|c|c|c|c|c|c|}
\hline \multicolumn{2}{|c|}{ Diving Depth } & \multirow{2}{*}{$\begin{array}{l}\text { Diving } \\
\text { time } \\
\text { minutes }\end{array}$} & \multicolumn{3}{|c|}{ Decompression Stages } & \multirow{2}{*}{$\begin{array}{c}\text { Total Ascent Period } \\
\text { Minutes }\end{array}$} \\
\hline Feet & Meters & & $19 \mathrm{ft}=6 \mathrm{~m}$ & $13 \mathrm{ft}=4 \mathrm{~m}$ & $6 \mathrm{ft}=2 \mathrm{~m}$ & \\
\hline \multirow[t]{2}{*}{22} & \multirow[t]{2}{*}{7} & 310 & & & 1 & 2 \\
\hline & & 320 & & & 2 & 3 \\
\hline \multirow[t]{3}{*}{25} & \multirow[t]{3}{*}{8} & 200 & & & 1 & 2 \\
\hline & & 210 & & & 2 & 3 \\
\hline & & 230 & & & 7 & 8 \\
\hline \multirow[t]{3}{*}{31} & \multirow[t]{3}{*}{10} & 100 & & & 1 & 3 \\
\hline & & 110 & & & 3 & 5 \\
\hline & & 120 & & & 5 & 7 \\
\hline \multirow[t]{3}{*}{38} & \multirow[t]{3}{*}{12} & 60 & & & 1 & 3 \\
\hline & & 70 & & & 2 & 4 \\
\hline & & 80 & & & 7 & 9 \\
\hline \multirow[t]{3}{*}{44} & \multirow[t]{3}{*}{13} & 50 & & & 1 & 3 \\
\hline & & 60 & & & 8 & 10 \\
\hline & & 70 & & & 14 & 16 \\
\hline \multirow[t]{3}{*}{50} & \multirow[t]{3}{*}{15} & 40 & & & 1 & 4 \\
\hline & & 50 & & & 10 & 13 \\
\hline & & 60 & & & 17 & 20 \\
\hline \multirow[t]{3}{*}{56} & 17 & 30 & & & 1 & 4 \\
\hline & & 40 & & & 7 & 10 \\
\hline & & 50 & & & 18 & 21 \\
\hline 63 & 19 & 25 & & & 1 & 4 \\
\hline & & 30 & & & 3 & 6 \\
\hline & & 40 & & & 15 & 18 \\
\hline 69 & 21 & 20 & & & 1 & 5 \\
\hline & & 25 & & & 3 & 7 \\
\hline & & 30 & & & 7 & 11 \\
\hline 75 & 23 & 15 & & & 1 & 5 \\
\hline & & 20 & & & 2 & 6 \\
\hline & & 25 & & & 6 & 10 \\
\hline 82 & 25 & 10 & & & 1 & 5 \\
\hline & & 15 & & & 2 & 6 \\
\hline & & 20 & & & 4 & 8 \\
\hline 88 & 27 & 10 & & & 1 & 6 \\
\hline & & 15 & & & 2 & 7 \\
\hline & & 20 & & & 6 & 11 \\
\hline 94 & 29 & 5 & & & 1 & 6 \\
\hline & & 10 & & & 2 & 7 \\
\hline & & 15 & & & 3 & 8 \\
\hline & & 20 & & 2 & 7 & 14 \\
\hline 100 & 31 & 5 & & & 1 & 6 \\
\hline & & 10 & & & 2 & 7 \\
\hline & & 15 & & 1 & 4 & 10 \\
\hline & & 20 & & 3 & 11 & 19 \\
\hline 107 & 33 & 5 & & & 1 & 7 \\
\hline & & 10 & & & 2 & 8 \\
\hline & & 15 & & 2 & 5 & 13 \\
\hline & & 20 & & 4 & 15 & 25 \\
\hline 113 & 34 & 5 & & & 1 & 7 \\
\hline & & 10 & & & 3 & 9 \\
\hline & & 15 & & 3 & 6 & 15 \\
\hline & & 20 & 1 & 5 & 17 & 29 \\
\hline 119 & 36 & 5 & & & 1 & 7 \\
\hline & & 10 & & 1 & 3 & 10 \\
\hline & & 15 & & 4 & 7 & 17 \\
\hline & & 20 & 2 & 6 & 20 & 34 \\
\hline
\end{tabular}




\section{LAKE TSO MORARI}

Lake Tso Morari is located in the Ladakh region of the Himalayas at an altitude of 4900 m. corresponding to a typical barometric pressure of 451 Torr.

Here, the SESD factor is equal to $[(760-47) /(451-47)]^{*}[1000 / 1033]$ or 1.709 . A dive at Lake Tso Morari of $35 \mathrm{~m}$ corresponds to an sea dive of $60 \mathrm{~m}$. The maximal depth of this lake is said to be $30-35 \mathrm{~m}$. A dive table for this lake can be developed.

\section{Discussion}

A recent review suggests the use of staged decompression for the reduction of decompression sickness for non-decompression dives (Gordon 1996). In order to reduce the risk of DCS further, we suggest to use an extra stop at the last decompression stage (3 $\mathrm{m}$ for sea diving) for $1 \mathrm{~min}$ also after non-decompression dives. Bubbles have been recorded with ultrasound even from a saturation dive to less than $5 \mathrm{~m}$.

The values in $\mathrm{m}$ for the former US yard and the imperial yard are both so close to the value for the unified yard (0.9144) - and thus the "unified foot " used in this report - that the minor conversion differences between feet and meters for dives up to $60 \mathrm{~m}$ are immaterial.

Previous models differ from ours in the following way: First, the effect of the water vapour pressure in the inspired tracheal air was not included. This factor increases in importance with altitude. Second, the difference between the density of fresh water and 
sea water were not included. Third, the decompression stops are not corrected for use at altitude. Fourth, the ascent rate at altitude is not corrected either.

The Buhlmann altitude diving tables (2005) are divided into groups covering 0-700 m and 700-2500 m. They present extended details which seem difficult for a practical dive.

Our model - and hereby our tables - assume that the body is a black box, so we need not consider maximum allowable nitrogen tissue tensions for a single dive per day on compressed air. The dive table presented here for Lake Titicaca is based on the US Navy sea dive table adapted and modified by us, and it is being tested at the High Altitude Naval Diving School at Lake Titicaca, Bolivia (3800 m).

Noteworthy is the fact that the Total Ascent Period remains the same for comparable dive depths in all our tables - a result of the correct mathematical procedure. The numerator (diving depth) and the denominator (ascent rate) are both subjected to the SESD correction. 


\section{Recommendations}

1. Any compressed air dive up to a maximum of 60 meters at sea level (or any comparable altitude dive) should always stop the ascent at the last stage for 1 minute for proper off gassing. - The classical decompression stages (30, 20 and 10 feet or 9, 6 and 3 m) are corrected to the lake altitude level by dividing the stage value with the SESD factor.

2. The ascent rate at altitude is crucial and should always be slower than at sea level. The Lake ascent rate is equal to the Sea ascent rate divided by the SESD factor.

\section{Precautions}

These equations and calculations must be used as guidelines only. An sea dive depth of $60 \mathrm{~m}$ is generally agreed to be the limit for professional compressed air dives.

Diving requires knowledge and several variables must not be overlooked: Adequate and quality equipment, diver's health condition and body temperature, quality compressed air etc. Hence we assume no responsibility. If suspicion of DCS occurs, use supplementary oxygen on open mask during transportation to a recompression chamber for proper treatment. 


\section{References}

Bell RL, Borgwardt RE (1976) The theory of high-altitude corrections to the US Navy Standard Decompression Tables. The Cross corrections. Undersea Biomed Res 3 (1): 123.

Boni M, Schibli R, Nussberger P, Buhlmann AA (1976) Diving at diminished atmospheric pressure: air decompression tables for different altitudes. Undersea Biomed $\operatorname{Res} 3$ (3): 189-204.

Buhlmann AA. (1984) Decompression/Decompression Sickness. Springer-Verlag, Berlin.

Buhlmann AA. Diving Tables. http://www.diving.co.za/buhlmann_dive_tables.htm. Accessed April 15, 2005.

Gordon G (1996) Staged decompression following no-decompression diving. SPUMS J. 26(2):131-5.

Hennesy TR (1977) Converting standard air decompression tables for no-stop diving from altitude or habitat. Undersea Biomed Res 4 (1): 39-53.

Kizer, KW (2001) Diving medicine. In: Paul S. Auerbach in Wilderness Medicine. $4^{\text {th }}$ Ed. Mosby Inc. St. Louis , Mo: 1395

Sahni TK, John MJ, Dhall A, Chatterjee AK (1991) High Altitude dives from 7,000 to 14,200 feet in the Himalayas. Undersea Biomed Res 18 (4): 303-16.

US Navy Diving Manual. (1963) NAVSHIPS 250-258, Dept. of the Navy, Washington DC, US Govt. Printing Office. 